DOI: 10.20472/IAC.2018.001.005

\author{
SUWANNEE KIRAHAT \\ Suan Sunandha Rajabhat University, Thailand \\ NOPADOL BURANANUTH \\ Suan Sunandha Rajabhat University, Thailand
}

\title{
FACTORS INFLUENCING A DECISION TO CHOOSE A UNIVERSITY: A CASE OF SUAN SUNANDHA RAJABHAT UNIVERSITY
}

\begin{abstract}
:
The main objective of this research was to study the potential students' decision to choose a university for their education. This study used Suan Sunandha Rajabhat University, Bangkok, Thailand as a case study as the university has been ranked as the best university in the Rajabhat system for many years. A quantitative research methodology approach was employed in this study. The research sample consisted of 400 high school students in Bangkok. Data were collected with the use of a questionnaire and analyzed with descriptive statistics. The research findings showed that the main reason that made the respondents choose to study at this university was its reputation as the best university in the Rajabhat system. This reason was rated the highest level. This was followed by the number of students in the undergraduate and postgraduate programs.
\end{abstract}

\section{Keywords:}

Students, Decision-making, University

JEL Classification: Y80 


\section{Introduction}

At the present time, Thai education has significantly expanded. This is evidenced by an increased number of newly opened campuses of higher education institutions. Education is an efficient means for human resource management. It is also regarded as a development mechanism for the country.

Education has been used to enhance knowledge, abilities, and skills for people in the country. The current age is regarded as a learning age where knowledge and wisdom is used to develop potentials for the country and represents the country's competitive advantage. Many countries are aware of the significance of education and start to review the efficiency of their educational system seriously in order to adjust it to be consistent with the current situation. These countries determine the vision for the development by focusing on education and taking advantage of modern technology. They set education as their national agenda.

Higher education or the education at the university level is very significant for people and the country because it involves creating and developing higher level of knowledge and skills that are necessary for the development of the nation. It also involves research, academic services, and cultural conservation. Therefore, it is a source of various fields of knowledge.

At the present time, demand for the study in the university level has been significantly increased, especially in Thailand where education is a sign of success. Universities has been developing new programs to meet with such demand. Moreover, these universities have also developed their learning and teaching methods by using new technology and innovations.

A decision to study at the university is very important for Thai students and their family as it can determine their future career. With this reason, the researcher was interested to examine factors affecting the students' decision to study at the university by using a case of studying at Suan Sunandha Rajabhat University, Bangkok, Thailand. This university was selected as a case because it is one of the most famous universities in Thailand. Moreover, it has been ranked as the best university in Rajabhat system for many years. The results of this study were expected to provide an insight for the university to develop new programs as well as to develop learning and teaching activities. 


\section{Research Objectives}

This study aimed to:

1) Study demographic background of the students who selected to study at Suan Sunandha Rajabhat University;

2) Examine reasons/motivations of these students in selecting to study at the university; and

3) Study factors affecting the students' decision.

\section{Scope of the Research}

Scope on the content

This study focused on the influence of students' demographic profile, needs/motivations, and other factors on the decision to study at Suan Sunandha Rajabhat University.

Scope on variables

The variables of this study can be divided into 2 groups:

1) Independent variables include students' demographic profile, their needs/motivations, and other influencing factors

2) Dependent variable is the students' decision to study at the university.

Scope on the study period

This study was conducted between August and September 2018.

Scope of the place of study

This research was conducted at Suan Sunandha Rajabhat University, Bangkok, Thailand.

Scope of the population

The population of this study were the undergraduate students of Suan Sunandha Rajabhat University. 


\section{Research Methodology}

This study aimed to examine the relationship between the independent variables, including the students' demographic background, their needs/motivations, and other factors, and the dependent variable which was the students' decision to study at the university, therefore, it used a quantitative research methodology.

\section{Population and sample}

The population of this study were the students of Suan Sunandha Rajabhat University who, at the time of conducting this research, were studying in the undergraduate level. The sample of the study were selected by using simple random sampling. The sample size was calculated by using Taro Yamane Formula. As a result, 400 students were selected.

\section{Data collection}

Data were gathered via a questionnaire which was developed by the researcher.

Data analysis

Data were analyzed with descriptive statistics.

\section{Research Results}

According to the data analysis, it was found that the students decided to study at Suan Sunandha Rajabhat University by considering at the reputation of the university as having been ranked as the best university in the Rajabhat system most. The mean score for this factor was 4.57 . The students expected to gain good quality of study in terms of academic standard as well as to receive high quality of services. They also wanted to be proud that they were accepted to be students in the high quality and well-known university of the country.

The results also showed that the students expected to have good career or be able to find a suitable job easily after being graduated. The mean score for this factor was 4.33. Moreover, students also considered at the rate of the fee and other expenses as well as the facilities and environment. 


\section{Suggestions}

1. As the results revealed that the students paid the highest attention at the reputation of the university, the university should do everything to remain its reputation and academic standards.

2. The university should determine the fee rate, including the study fee, the maintenance fee, and fee for laboratories (if any), that is appropriate for the students and consistent to the current economic situation. This is because moneyrelated factor is significant.

3. The university should also provide sufficient and appropriate facilities for the students. It should also attempt to provide safe and good environment that support learning and teaching activities. This can help create good attitude for the students. In a case that the university needs to open a new campus, it should choose a location that is near the community.

\section{References}

Phoyen, K. ( 2 007). Factors Affecting Students Decision to Continue Undergraduate Stuidy at Bansomdejchaopraya Rajabhat University. Unpublished Independent Study. Chiang Mai: Chiang Mai University.

Tepsumethanon, T., \& Sirapitool, S. (2010). Factors in Choosing a Bachelor's special program in a law, Faculty of Law, Ramkhamhaeng University. Ramkhamhaeng University, 27(1).

Thumavihankun, P. (2009). Factors of decision making to take Accounting major, Business management, Faculty of Management Science Chandrakasem Rajabhat University. Unpublished independent study. Bangkok: Chandrakasem Rajabhat University.

Vichitakul, P. (2011). Factors affecting decision to study at Faculty of Engineering, Rajamangala University of Technology Thanyaburi. Unpublished independent study. Pathum Thani: Rajamangala University of Technology Thanyaburi. 